Old Dominion University

ODU Digital Commons

2016

\title{
STEM in General Education: Does Mathematics Competence Influence Course Selection
}

Mary C. Enderson

Old Dominion University

John Ritz

Old Dominion University

Follow this and additional works at: https://digitalcommons.odu.edu/stemps_fac_pubs

Part of the Higher Education Commons, and the Science and Mathematics Education Commons

\section{Original Publication Citation}

Enderson, M. C., \& Ritz, J. (2016). STEM in general education: Does mathematics competence influence course selection. The Journal of Technology Studies, 42(1), 30-40. doi: 10.21061/jots.v42i1.a.3

This Article is brought to you for free and open access by the STEM Education \& Professional Studies at ODU Digital Commons. It has been accepted for inclusion in STEMPS Faculty Publications by an authorized administrator of ODU Digital Commons. For more information, please contact digitalcommons@odu.edu. 


\section{STEM in General Education: Does Mathematics Competence Influence Course Selection By Mary C. Enderson and John Ritz}

\begin{abstract}
Many students enroll in college programs to prepare for their future careers. All are required to complete general studies courses. At one university, technology and STEM courses fulfill a part of the natural science and technology general education requirements. This study uses a survey design to explore why 332 students chose to enroll in a STEM technology course. Results found most enroll because their advisor suggests the course, it meets a general education major requirement, and the course is offered at a convenient time. Fewer enroll in the course because they would like to find out more about STEM fields, be exposed to potential careers, or because of the implicit need to study STEM subjects. Student mathematics skills were analyzed to determine if these skills influenced their choice for selecting this technology STEM course.
\end{abstract}

Keywords: STEM in general education, STEM and mathematics, elective selection

\section{INTRODUCTION}

STEM is an acronym that has been discussed and tied to the economy and education. Spurred by the economic recession of 2008, policy leaders around the world believe there is a need to increase the number of science, technology, engineering, mathematics, and medical graduates from colleges and universities (Gates \& Mirkin, 2012). Competitiveness through innovation seems to be a key in keeping economies growing and people working - working at well-paying jobs. Within the evolving world marketplace, countries that develop technological innovations thrive in the marketplace and drive economic development (e.g., fuel cell vehicles, nextgeneration robotics, precise genetic engineering techniques, emergent artificial intelligence, distributed manufacturing, and "sense and avoid" drones) (Meyerson, 2015).

World leaders want their citizens to compete for good jobs within the global economy. To do this, the emerging workforce will need advanced knowledge and skills. The improved study of science, technology, engineering, and mathematics can create pathways that provide the education that leads to the creation of new products, particularly knowledge of technology (Committee on Prospering in the Global Economy of the 21st Century, 2007). According to the National Academies, many innovative products result from "four percent of the nation's work force [which] is composed of scientists and engineers" (Rising Above the Gathering Storm Committee, 2010, pp. 2-3). Their innovations often support the employment of most other workers.

Why are so few students preparing for or choosing to major in STEM subjects? Some researchers believe the image of STEM careers and STEM subject difficulties are two prohibiting factors (Jahn \& Myers, 2015; Wyss, Heulskamp, \& Siebert, 2010). The study of advanced levels of mathematics has been reported as a detriment to more students studying STEM subjects (Petroski, 2015). If students select to enroll in STEM elective courses at the university level, why did they choose to do this? Because universities are acknowledging that their responsibilities extend beyond producing the next generation of scientists, technologists, engineers, and mathematicians, some are recognizing that the challenge is to equip students with the scientific and technical literacy and numeracy required to play meaningful roles in society (Gates \& Mirkin, 2012). In some instances, these roles may not be directly tied to STEM careers but to other professions that may benefit from general coursework in STEM studies. Such experiences may find a place for general education elective courses designed to provide general STEM knowledge.

Over a century ago, Dennett (1886) did not understand the value in students' taking elective university courses unless these originated from a reasonable cause. At the university where this study was undertaken, there was a major shift in the general education curriculum in 1994. Prior to this time, the goal of general education was to provide a liberal education for all. During the revision, the general education review committee chose to re-design the 
general studies curriculum to be more focused on student needs and the knowledge students would need to be successful in their selected major. After the redesign, composition remains a cornerstone of the curriculum, as does mathematics, science, and the social sciences. However, expanded philosophical views were woven into the new general studies curriculum. One goal was to develop an understanding of the natural sciences and technology and their contributions to human culture. In addition to this goal, an objective was added: students should understand the nature of technology and its impacts on society and the environment.

Using this revised goal as leverage, one department created a course titled Technology in Your World. It is one of several courses students can select from to fulfill the technology requirement. This course has proven to fulfill a reasonable cause (Dennett, 1886) and it is often selected by students to meet the technology literacy requirement. According to the university undergraduate catalog, the course is described as "an overview of the resources and systems of technology. Emphasis is on impacts that technology has on individuals and their careers. Activities explore the evolution of technology, its major systems and their impact on individuals and their careers" (Old Dominion University, 2015, p. 466). Although this course focuses primarily on the study of technology, aspects of science, engineering, and mathematics are introduced during laboratory investigations. This course includes an overview of major technological systems and it requires hands-on activities designed to show students how technology is applied in various careers. Some university majors fulfill this requirement through technology courses required by their major program.

This study investigated why students chose to enroll in this university general education course. Elective courses are used to increase students' levels of awareness, acceptance, and understandings (Evans, 2006). Research by Ting and Lee (2012) explained that students select electives for various reasons, including (a) perceived interest of the subject, (b) perceived difficulty of subject material, (c) perceived leniency of the lecturer, $(d)$ exposure to future career skills, (e) influence of others, (f) popularity/personality of lecturer/quality of teaching, (g) day of the week and meeting hour, (h) reputation of the university, (i) suitability of the subject, and (j) size of class. This study explored these variables to determine students' reasons for selecting such a course. It also explored students' backgrounds in high school mathematics and the depth of mathematics they had completed at the university level prior to selecting this course.

\section{LITERATURE REVIEW}

This study's review of literature explores STEM and its perceived relationship to the development of the economy. It also reviews technological literacy and its relationship to STEM. Finally it investigates the relationship of mathematics knowledge and abilities to the success of STEM majors. These areas are presented because they are relevant to a student's studying STEM through university coursework and the way STEM can support or challenge the student's selection of a STEM major or preparation for other future careers.

\section{STEM AND THE ECONOMY}

The post WWII economy grew and required increased labor in the manufacturing and construction industries (Conte, Karr, Clark, Hug, \& Manning, 2001). There was demand for consumer and industrial products and housing as the American economy grew. Muscle and a high school education did well for laborers. The Cold War Era saw a demand for higher education for engineers and scientists who would develop systems to process and mass produce food, automobiles, appliances, and electronic products, and then develop the systems to move products and people around the country and world. The growing economy demanded an increasing reliance on advancing technologies. Engineers and scientists produced lightweight metals and plastics, jetliners, high-rise buildings, and food to feed the increasing population.

Education in science, technology, engineering, and mathematics has continued through various funding streams since the Cold War (Haugsbakk, 2013). In addition to government efforts, business and industry, and their foundations, needed additional STEM education to provide the innovative workers required in the nation. According to Gates and Mirken (2012), insufficient numbers of students are majoring in science, engineering, and medical professions. The technology workforce is also in short supply. In addition to college graduates, there is demand for two-year technical graduates and graduates 
of career and technical education programs. It is estimated that 600,000 skilled workers are needed for current manufacturing jobs (Sirkin, 2013). STEM skills continue to be in demand.

\section{TECHNOLOGICAL LITERACY}

To function effectively in society, citizens must have knowledge of the technology around them. They should understand some technologies at the macro-level, and they should be familiar with specific technologies needed in their life and work pursuits. For instance, it is good to understand what STEM cell research is and that it might someday improve your life (macro-level). It is also important that a person become more familiar with a computing system at the microlevel (e.g., which system is most appropriate to purchase, how to change a printer cartridge to continue to have quality output). These are literacies - technological literacies.

To function in a society, a person understands spoken words, reading and writing, and general mathematics (general literacies). In the U.S. Workforce Investment Act of 1998, literacy is defined as "an individual's ability to read, write, speak in English, compute and solve problems at levels of proficiency necessary to function on the job, in the family of the individual and in society" (p. 131). In addition to these general literacies, some educators believe all people need:

A new form of literacy - a technological literacy ... This is a vital necessity if citizens are to participate in assessing and determining the relationship of technological systems to human needs. To function in this role requires that all citizens be conversant in the language of technological systems and comprehend basic concepts of the dynamics of the interrelated systems for all levels of society. (DeVore, 1980, p. 338)

Technological literacy is defined as "the ability to use, manage, understand, and assess technology" (ITEA, 2000, p. 242). However in practice, technology has at times been focused on developing technical expertise, instead of how useful or pertinent the technologies can be (Ginestié, 2008). To "understand, use, assess, and manage technology" (ITEA, 2000, p. 242) is much different than to develop expertise in a few technologies, such as robotics and machining. According to Pearson and Young (2002):
Technological literacy is not the same as technical competency. Technically trained people have a high level of knowledge and skill related to one or more specific technologies or technical areas ... a technologically literate person would not necessarily require extensive technical skills. Technological literacy is more of a capacity to understand the broader technological world rather than an ability to work with specific pieces of it. (pp. 21-22)

Because much of the world continues to experience new technologies and changing economic situations, and the general higher education system is almost void in explaining these developments and how or if they should be used for the betterment of society, such knowledge and abilities should eventually become one focus of education through technology studies programs. Pearson and Young (2002) stated that "technological literacy - an understanding of the nature and history of technology, a basic hands-on capability related to technology, and an ability to think critically about technological development - is essential for people living in a modern nation ..." (pp. 11-12). Such people have knowledge of technology and are capable of using it effectively to accomplish various tasks. They can think critically about technological issues and act accordingly. Technological literate people would possess knowledge, ways of thinking and acting, and capabilities that assist them as they interact with the technology found in their environments. These knowledge and skills align with those specified in Standards for Technological Literacy: Content for the Study of Technology (ITEA, 2000). These types of outcomes were used at the institution where this study took place. Faculty developed a general technological literacy course for a general population of students, and they worked to have it fulfill the science and technology requirement of the university's general education program. In the class, technological concepts and principles were taught, and students applied this knowledge through laboratory activities (see Ritz, 2011 for a detailed description of the course outcomes and assessments).

\section{MATHEMATICS AND STEM}

The role of mathematics in STEM is often seen as a tool to solve problems in science, technology, and engineering. Mathematics as a discipline involves numerical, spatial, and logical relationships used to make sense of or solve 
problems (Vilorio, 2014). Although the study of mathematics as a college major is not widespread, the concepts and ideas of mathematics permeate across various disciplines. Mathematics finds its place in many of the non-science fields, including art, business, communication, criminal justice, language, music, recreation, and sports management. Work in these fields includes mathematics concepts focused on computations as well as applications in areas centered on budgets, rhythms and beats, shapes and colors, logic, accident evidence and data, tracking scores and game statistics, and recreational terrains and geographical data. Students who major in such non-science fields are often required to take one to two mathematics courses typically focused on college algebra and statistics.

STEM as a career choice or some component of STEM as a major typically begins prior to university study. High schools usually offer courses in advanced mathematics (e.g., calculus, AP calculus) that provide a solid foundation for students entering a university with an interest in one of the STEM disciplines. Mathematics provides one with critical thinking skills that involve studying problems from different angles as well as using problem solving techniques to find solutions. It teaches a person how to approach tasks methodically, pay attention to details, and to think abstractly - qualities that many employers appreciate (Torpey, 2012). Being able to discuss the mathematics used in solving problems requires a sound understanding of concepts and how they connect across various disciplines.

The United States has witnessed a decline in the STEM workforce, which causes a void in STEM careers and job opportunities. Studies and reports document the challenges students face in acquiring success in mathematics as they complete high school and consider enrollment in college/university studies or progression into the labor market. High-level mathematics in high school is a powerful predictor of success in work and life regardless of a person's choice to attend college or enter the workforce (Peckham, 2015). For a number of years, the ACT, SAT, and the Educational Policy Improvement Center have been tackling issues surrounding career and college readiness. Mathematics is one area identified in several reports that indicate students need a thorough understanding of basic mathematics concepts as well as problem solving to interpret, understand, and analyze real problems (Conley, 2011) both at the college level and in the workplace.
Mathematics is one strand of STEM literacy, which involves weaving together knowledge for each discipline - science, technology, engineering, and mathematics. In the case of mathematics, it is an individual's ability to understand the role of mathematics in the world around him/her and to use the mathematics to make sound decisions. Such mathematics literacy is defined as, "An individual's capacity to identify and understand the role that mathematics plays in the world, to make well-founded judgments, and to use and engage with mathematics in ways that meet the needs of that individual's life as a constructive, concerned and reflective citizen" (OECD, 2009, p. 84). In addition, the OECD (2013) recently established that literacy, numeracy, and problem solving skills were linked to positive work outcomes, including employment and earnings. Regardless of whether a student declares a major in mathematics or some other discipline, being mathematically literate is of utmost importance in resolving problems and situations and to produce citizens who are ready for today's workforce. This study sought to see if mathematics competence had a relationship to students' decisions to enroll in this STEM technology course.

\section{RESEARCH PROBLEM AND QUESTIONS}

The problem of this study was to determine the influence that mathematics competence has on students' decisions to enroll in STEM courses. This problem arose because of the curiosity of the researchers working at a university and meeting students who change majors due to their perceived weaknesses in mathematics.

To guide this study, the following research questions were developed:

RQ1: What prompts students to enroll in a general education STEM course?

RQ2: Is there a relationship between student competence in mathematics and the enrollment in STEM courses and majors?

\section{METHODOLOGY}

With such a strong STEM push in future careers and workforce opportunities, researchers were interested to know more about the mathematics background of students in this specific lower level STEM course. Because mathematics plays a vital role in STEM, the researchers believed that students who would be enticed to take the 
STEM general education course would also have strength in mathematics either through high school coursework or through their identification as a STEM major. Thus, the researchers adopted a quantitative study design. The research design selected for this study was the survey method, a nonexperimental quantitative research tool. Fraenkel, Wallen, and Hyun (2012) identified the survey as a method to "describe the characteristics of a population" (p. 393). These authors noted that in other types of research "the population as a whole is rarely studied" (p. 393), the survey method allows for a "carefully selected sample of respondents" (p. 394) to be surveyed, and a "description of the population is inferred from what is found out about the sample" (p. 394). For purposes of this study, a cross-sectional survey was administered to gather information from a predetermined population at a predetermined point in time. Gay, Mills, and Airasian (2012) noted that cross-sectional designs are "effective for providing a snapshot of the current behaviors, attitudes, and beliefs in a population" (p. 185). Creswell (2012) stated that a cross-sectional survey design has the "advantage of measuring current attitudes or practices" (p. 377).

\section{PARTICIPANTS AND DATA} COLLECTION INSTRUMENT

The participants involved in this research were undergraduates enrolled in a STEM 110 level course, Technology and Your World, which was designed for a general population. This general education course met a university technology studies requirement and was strongly recommended to students by various major advisors. During the fall term 12 sections of the course were offered with approximately 400 students enrolled. The university studied had a diverse undergraduate student representation: 55.9\% White, 23.8\% Black, 6.2\% Hispanic, and $4.2 \%$ Asian. Fifty-five percent of the undergraduate population was noted as female (StateUniversity.Com, 2016). The university in this study was classified as a metropolitan research one university.

A survey was designed based upon the research questions and knowledge of elective course selection and mathematics performance found in the literature. The survey was distributed during the first week of classes, so influence by the various instructors who taught this course should have had little impact on student responses. Student participation in the study was voluntary. The survey was one page in length and was comprised of two parts. Part 1 asked students to select and rank their top three choices/ reasons why they selected to take the course. Nine responses were listed: (a) Required for my major, (b) Interested in finding more about STEM fields, (c) Course offered at a convenient time (day and time), (d) Level of difficulty of the class, (e) Popularity of the instructor, (f) Exposure to future career skills, (g) Influence of others (peers, parents, advisor, others), (h) Reputation of the need to study STEM subjects, and (i) Class size influences my course selection. Part 2 of the survey focused on identifying participants' mathematics background that included prior high school mathematics courses and college-level mathematics coursework completed since entering the university. Part 3 asked for student major and if undecided, what discipline(s) the student was considering. Data were collected anonymously. The course instructors distributed surveys at the end of the first week of classes. Students who chose to participate placed completed surveys into an envelope when they exited the classroom and hence were nonidentifiable by the instructors and researchers. No identifying information was collected on the surveys.

\section{DATA ANALYSIS AND FINDINGS}

Out of the $n=414$ registered students, $332(N)$ returned completed surveys. According to Krejcie and Morgan (1970), an acceptable number of returns fall between 196 (given $n=400$ ) and 201 (given $n=420$ ), which more than meets the recommended sample size. The calculated confidence level for these data was $99 \%$ with a confidence interval of 3.2. Data, which were selfreported, from the 332 participants were used to address the research questions for this study.

The first research question was focused on the motivation of students who enroll in a STEM general education course. Participants were provided with nine choices to select from in responding to the question and were requested to identify up to three choices in rank order (e.g., 1,2 , and 3). The results show "required for my major" to be selected by $281(84.6 \%)$ participants as a choice for taking the STEM technology course. After this preference, "course day and time" was next with $109(32.8 \%)$ responses. Beyond these two selections, other options did not receive as many responses with several in the $80 \mathrm{~s}$ - influence of others, level of difficulty of 
the course, and exposure to future career skills, followed by interest in finding out more about STEM, popularity of instructor, reputation of the need to study STEM, and finally class size. Table 1 identifies the choices and the number of respondents who selected each one and the percentage of respondents for each category.

Table 1: Responses for Selecting the STEM Course

\begin{tabular}{|c|c|c|}
\hline Responses & $\begin{array}{l}\text { Number } \\
\text { Selected }\end{array}$ & Percent \\
\hline Required for my major & 281 & $84.6 \%$ \\
\hline $\begin{array}{l}\text { Interested in finding } \\
\text { more about STEM } \\
\text { fields }\end{array}$ & 79 & $23.8 \%$ \\
\hline $\begin{array}{l}\text { Course offered at a } \\
\text { convenient time (day } \\
\text { \& time) }\end{array}$ & 109 & $32.8 \%$ \\
\hline $\begin{array}{l}\text { Level of difficulty of } \\
\text { the class }\end{array}$ & 87 & $26.2 \%$ \\
\hline $\begin{array}{l}\text { Popularity of the } \\
\text { instructor }\end{array}$ & 56 & $16.9 \%$ \\
\hline $\begin{array}{l}\text { Exposure to future } \\
\text { career skills }\end{array}$ & 85 & $25.6 \%$ \\
\hline $\begin{array}{l}\text { Influence of others } \\
\text { (peers, parents, } \\
\text { advisor, others) }\end{array}$ & 88 & $26.5 \%$ \\
\hline $\begin{array}{l}\text { Reputation of the } \\
\text { need to study STEM } \\
\text { subjects }\end{array}$ & 49 & $14.8 \%$ \\
\hline $\begin{array}{l}\text { Class size influences } \\
\text { my course selection }\end{array}$ & 23 & $6.9 \%$ \\
\hline
\end{tabular}

In addition to studying reasons why students enroll in a STEM introductory course, the researchers were interested to determine if a relationship exists between competence in mathematics and interest/enrollment in a STEM course. Participants were asked to identify what mathematics courses they completed in high school as well as in college. The literature in career and college readiness indicates students who are interested in STEM fields need greater levels of mathematics prior to attending college/ university (Gates \& Mirkin, 2012). More than $60 \%(N=202)$ of respondents indicated that they had taken both geometry and algebra 2 in high school. This signifies that the participants were academically beyond a secondary algebra 1 course of mathematics. From a college and career readiness perspective, such students would more than likely begin their mathematics coursework at or below the college algebra level, and thus would not have a strong mathematics background to seriously consider a major in STEM or a related STEM discipline.

Subsequent to geometry and algebra 2 , approximately $33 \%(N=109)$ completed a pre-calculus course and less than $17 \%(N=56)$ completed a calculus course - some completing regular calculus and others completing advanced placement calculus. Such outcomes document a small number of secondary students who are well positioned for serious study of STEM in college or in the workplace. Other research has provided evidence that entering a university with more rigorous mathematics coursework prepares students for future study of STEM, which in turn can help fill the STEM pipeline (Tyson, Lee, Borman, \& Hanson, 2007).

At the university level, researchers found that approximately $37 \%(N=124)$ completed college algebra, while the next course that appeared with regularity was statistics at $30 \%(N=100)$. Numbers were quite low for pre-calculus $(N=49)$ and calculus $(N=45)$, which supports the lack of mathematics completion in secondary school prior to university study. According to the data 11 participants took business calculus, which is appropriate for business majors rather than STEM majors. Overall, very little mathematics showed up for this particular sample, which compelled researchers to take a closer look at the college majors participants identified on the survey instrument. Non-science majors often do not enroll in advanced or upper level mathematics courses that are not a part of their program of study, whereas typically STEM majors take a significant amount of mathematics (usually through calculus).

The results were supported by two chisquare analyses of the data. The first analysis concentrated on STEM and non-STEM majors and the level of mathematics participants completed. Mathematics coursework was identified as high level if participants completed pre-calculus or higher level math courses and identified as low level if coursework was lower than pre-calculus. The result for this particular chi-square analysis was 37.276 (with one degree of freedom) and was significant at the $\mathrm{p}<.01$ 
level; $\chi^{2}(1)=37.276, p<.01$. This analysis confirmed that non-STEM majors were more likely to complete lower levels of mathematics coursework.

The second chi-square analysis focused on level of mathematics courses completed and the grades participants received for the noted coursework. Again, the level of mathematics courses was considered high level if participants had completed pre-calculus or higher courses. Regarding the grade aspect of this analysis, A's and B's were considered high level and C's, D's, and F's were considered low level. The result of this chi-square analysis (with one degree of freedom) produced 6.653 and was found to be significant at the $p<.01$ level; $\chi^{2}(1)=6.653, p$ $<.01$. Thus, there appears to be a relationship between the level of mathematics courses taken and the grades received.

In addition to identifying the mathematics background students' possessed on the survey, participants were asked to identify the major or intended major. The top three programs identified through this STEM survey were Biology $(N=45)$, Criminal Justice $(N=41)$, and Psychology $(N=38)$. Out of these three majors, two fall in the College of Sciences, but they do not possess a heavy focus on mathematics coursework. In the case of Biology, students are not required to take mathematics coursework higher than pre-calculus or calculus 1. Psychology majors must take two 100-level mathematics courses (college algebra and elementary statistics). In both College of Science programs, the amount of mathematics is quite minimal and tends to fall at the lower end of the spectrum. The Criminal Justice program lies in the College of Arts and Letters, and, as is often the case, mathematics receives sparse attention. Criminal Justice majors are required to take an elementary statistics course, which also counts toward the completion of a 3-hour general education requirement. Thus, the three designated majors paint a picture of a low mathematics background of participants who enrolled in this STEM course. In addition to the three majors presented, 45 other majors were identified from survey data with a handful in areas such as chemistry, engineering, mathematics, physics, and modeling \& simulations $(N=22)$ that required more advanced coursework in mathematics. See Table 2 for majors identified in the survey and how many participants were in each category.
Table 2: Identification of Participants' Declared Majors

\begin{tabular}{|c|c|}
\hline Major & $\begin{array}{c}\text { Number of } \\
\text { Participants * }\end{array}$ \\
\hline Art & 5 \\
\hline Biology & 45 \\
\hline Civ. Eng./Civ. Eng. Tech. & 7 \\
\hline Communication & 31 \\
\hline Criminal Justice & 41 \\
\hline English & 6 \\
\hline Exercise science & 7 \\
\hline Health sciences & 5 \\
\hline Health services admin. & 5 \\
\hline Human services & 15 \\
\hline Mathematics & 5 \\
\hline Nursing & 8 \\
\hline Psychology & 38 \\
\hline Speech path. & 12 \\
\hline Sports management & 21 \\
\hline Supply chain management & 5 \\
\hline Therapeutic rec & 5 \\
\hline Tourism management & 9 \\
\hline Undeclared & 16 \\
\hline
\end{tabular}

NOTE: If less than 5 students indicated the subject as a major, it was not included in the table.

\section{DISCUSSION, IMPLICATIONS, \& RECOMMENDATIONS}

This study investigated why students elect to enroll in a STEM university general education course and if their mathematics background had any influence on their taking such a course. Evidence exists that far too many students lose interest in science, technology, engineering, and mathematics in middle and high school; as a result they exit out of the STEM pipeline - 
many even before arriving to college/university (Gates \& Mirkin, 2012). It is unfortunate to witness as the "T" and "E" - Technology and Engineering - often are valuable ways to apply science and mathematics. As has been well documented, many students are unprepared for the demands and expectations of postsecondary education (Conley, 2003). In one study, faculty identified critical thinking and problem solving as primary areas in which first-year students needed greater improvement (Lundell, Higbee, Hipp, \& Copeland, 2004). Since these processes are a major part of mathematics, researchers were interested in reasons why students take a STEM course as well as how the mathematics background fits in with the decision-making process.

In addition to concerns raised about lack of interest in STEM careers across the United States, other employers and businesses that are not STEM focused have expectations that align to similar concepts and ideas. The Association of American Colleges and Universities (AAC\&U) carried out a survey among business leaders: in it employers were asked to assess emphasis colleges and universities placed on learning outcomes (Hart, 2006). The survey revealed that employers believe higher education institutions should do more to achieve learning outcomes in multiple areas to ensure future employees will be successful contributing members in today's global economy. In a list of their top priorities, it was documented that greater emphasis should be placed on (a) critical thinking and analytical reasoning skills and (b) science and technology. In both of these instances, a general education STEM course can provide all fields with such emphases (Hart, 2006).

This particular STEM course was designed to expose any student, regardless of his/her major, to future career skills in the STEM fields $(N=85 ; 25.6 \%)$, to provide more information about STEM fields $(N=79 ; 23.8 \%)$, and to understand the reputation of the need to study STEM subjects $(N=49 ; 14.8 \%)$. Interesting, none of these points appeared relevant to the participants in this particular study. It would be interesting to determine if these findings are common to future semesters of the course offering and if so, why or if not, why not.

As this study was designed and carried out, researchers believed that there would be a greater number of STEM majors in the sample surveyed. However, very few participants were STEM majors $(N=73)$. It would be of interest to determine what course(s) such majors are taking in the STEM areas and how their mathematics background prepared them for such courses.

\section{CONCLUSIONS}

With today's STEM movement, the job market is searching for potential hires in the fields of science, technology, engineering, and mathematics. For college and university students not majoring in these disciplines, a STEM course may translate into looking for ways to strengthen or "round out" their educational experiences for future job opportunities. Elective coursework, in and out of the major, is one option that may fit this scenario. In other instances, electives may be part of the university's general education courses that are designed to expose students to the sciences (including mathematics and technology), humanities, writing and literature, and history. Both situations serve the purpose in complementing a student's degree. As Hachtmann (2012) stated, "Whereas knowledge of disciplinary facts and concepts used to be the emphasis, now the focus of student learning is on broadly defined competencies to ensure that students are well equipped to be responsible citizens and professionals upon graduation" (p. 19).

This study occurred at one university using a course with 12 sections offered to students during one semester. In this particular study it was found that university students who took a STEM course were prompted to enroll in it as a result of advising and that their mathematics background really was not a factor. It was also determined that most students in the STEM course that was used for this study, lacked an advanced mathematics background and were not taking advanced mathematics courses. This helped answer the second research question as to whether there is a relationship between a student's competence in mathematics and enrollment in a STEM course. This study did not find a strong relationship for this particular STEM course. Such results indicate that providing students, regardless of their degree major, options to take lower level STEM courses may benefit them in the long run by exposing them to basic STEM concepts and ideas. In turn, future employers may consider such experiences valuable to their workplace preparation and 
technology studies courses into the curriculum for all. If this occurs, courses should be created with knowledge of the mathematics background of students. Advisors' recommendations and course schedules are also important factors to consider in the students' selection of these types of elective courses.

Mary C. Enderson is Associate Professor in STEM Education and Professional Studies at Old Dominion University, Norfolk, VA.

John Ritz is Professor in STEM Education and Professional Studies at Old Dominion University. He is a member of Alpha Upsilon Chapter of Epsilon Pi Tau and has received the Laureate Citation. 
Committee on Prospering in the Global Economy of the 21st Century. (2007). Rising above the gathering storm: Energizing and employing America for a brighter economic future. Washington, DC: The National Academies Press.

Conley, D. T. (2003). Mixed messages: What state high school tests communicate about student readiness for college. Eugene, OR: Educational Policy Improvement Center.

Conley, D. T. (2011). Redefining college readiness, Volume 5. Eugene, OR: Educational Policy Improvement Center.

Conte, C., Karr, A. Clark, G., Hug, K. E., \& Manning, L. (2001). Outline of the U.S. economy, Washington, DC: U.S. Department of State, Office of International Information Program.

Creswell, J. W. (2012). Educational research (4th ed.). New York: Pearson.

Dennett, I. C. (1886). Elective studies in college. Education, 6(7), 575-579.

DeVore, P. W. (1980). Technology an introduction. Worcester, MA: Davis Publications, Inc.

Evans, E. (2006). An elective course in cultural competence for healthcare professionals. American Journal of Pharmaceutical Education, 70(3), 1-7.

Fraenkel, J. R., Wallen, N. E., \& Hyun, H. H. (2012). How to design and evaluate research in education (8th ed.). New York: McGraw-Hill.

Gates, Jr., S. J., \& Mirkin, C. (2012, June 25). Encouraging STEM students is in the national interest. The Chronicle of Higher Education. Retrieved from: http://chronicle.com/article/Encouraging-STEM-Students-Is/132425/

Gay, L. R., Mills, G. E., \& Airasian, P. (2012). Educational research (10th ed.). New York: Pearson.

Ginestié, J. (2008). The cultural transmission of artifacts, skills and knowledge. Rotterdam: Sense Publishers.

Hachtmann, F. (2012). The process of general education reform from a faculty perspective: A grounded theory approach. The Journal of General Education, 61(1), 16-38.

Haugsbakk, G. (2013). From Sputnik to PISA shock-New technology and educational reform in Norway and Sweden. Educational Inquiry, 4(4), 607-628.

Hart, P. D. (2006). How should colleges prepare students to succeed in today's global economy? Based on surveys among employers and recent college graduates (Conducted on behalf of The Association of American Colleges and Universities). Washington, DC: Peter D. Hart Research Associates, Inc.

International Technology Education Association (ITEA/ITEEA). (2000, 2005, 2007). Standards for technological literacy: Content for the study of technology. Reston, VA: Author.

Jahn, J., \& Myers, K. (2015). "When will I use this?" How math and science classes communicate impressions of STEM careers: Implications for vocational anticipatory socialization. Communication Studies, 66(2), 218-237.

Krejcie, R. V., \& Morgan, D. W. (1970). Determining sample size for research activities. Educational and Psychological Measurement, 30, 607-610.

Lundell, D. B., Higbee, J. L., Hipp, S., \& Copeland, R. E. (2004). Building bridges for access and success from high school to college: Proceedings of the Metropolitan Higher Education Consortium's developmental education initiative. Minneapolis, MN: Center for Research on Developmental Education and Urban Literacy, University of Minnesota. 
Meyerson, B. (2015). Top 10 emerging technologies of 2015. World Economic Forum. Switzerland: Davos-Klosters. Retrieved from: https://agenda.weforum.org/2015/03/ top-10-emerging-technologies-of-2015-2/\#neuromorphic-technology

Old Dominion University. (2015). Undergraduate catalog. Norfolk, VA: Author

Organisation for Economic Cooperation and Development (OECD). (2009). PISA 2009 assessment framework - Key competencies in reading, mathematics and science. Paris: Author.

Organisation for Economic Cooperation and Development (OECD). (2013). Time for the U.S. to Reskill?: What the survey of adult skills says, OECD Skills Studies. OECD Publishing, Paris: Retrieved from: http://dx.doi.org/10.1787/9789264204904-en

Pearson, G., \& Young, A.T. (2002). Technically speaking: Why all Americans need to know more about technology. Washington, DC: National Academies Press.

Peckham, S. (2015). Technically speaking. Tech Directions, 75(3), 2.

Petroski, H. (2015). Constraining courses: Math should not be a barrier to success in engineering. PRISM, 25(1), 8. Retrieved from: http://www.asee-prism.org/2015/09/page/8/

Rising Above the Gathering Storm Committee. (2010). Rising above the gathering storm revisited: Rapidly approaching category 5. Washington, DC: The National Academies Press.

Ritz, J. (2011). A focus on technological literacy in higher education. Journal of Technology Studies, 37(1). Retrieved from: http://scholar.lib.vt.edu/ejournals/JOTS/v37/v37n1/ritz.html

Sirkin, H. L. (2013). The coming shortage of skilled manufacturing workers. Retrieved from: http://www.bloomberg.com/bw/articles/2013-01-14/the-coming-shortage-of-skilledmanufacturing-workers

StateUniversity.Com. (2016). Old Dominion University. Retrieved from: www.stateuniversity.com/ VA/Old_Dominion_University.html

Ting, D. H., \& Lee, C. K. C. (2012). Understanding students' choice of electives and its implications. Studies in Higher Education, 37(3), 309-325.

Torpey, E. (2012). Math at work: Using numbers on the job. Occupational Outlook Quarterly, Fall issue, 2-13.

Tyson, W., Lee, R., Borman, K. M., \& Hanson, M.A.. (2007). Science, technology, engineering, and mathematics (STEM) pathways: High school science and math coursework and postsecondary degree attainment. Journal of Education for Students Placed at Risk, 12(3), 243-270.

Vilorio, D. (2014). STEM 101: Intro to tomorrow's jobs. Occupational Outlook Quarterly, Spring issue, 2-12.

Workforce Investment Act. U.S. Public Law 105-220 (Aug. 7, 1998).

Wyss, V. L., Heulskamp, D., \& Siebert, C. J. (2011). Increasing middle school students' interest in STEM careers with videos of scientists. International Journal of Environmental \& Science Education, 7(4), 501-522.

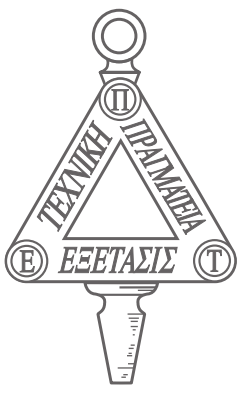

